\title{
Combinational approach using in situ hybridization targeting 23S ribosomal RNA genes and blood cultures for
} bacterial identification in patients with neutropenia and fever

Hideo Koh, Mizuki Aimoto, Akio Matsuhisa, Shin-Ichi Inoue, Takako Katayama, Hiroshi Okamura, Takuro Yoshimura, Shiro Koh, Satoru Nanno, Mitsutaka Nishimoto, Yasuhiro Nakashima, Asao Hirose, Mika Nakamae, Takahiko Nakane, Masayuki Hino, Hirohisa Nakamae

\begin{tabular}{|c|l|}
\hline Citation & Journal of Infection and Chemotherapy, 22(10); 697-703 \\
\hline Issue Date & $2016-10$ \\
\hline Type & Journal Article \\
\hline Textversion & Author \\
\hline \multirow{3}{*}{ Rights } & $\begin{array}{l}\text { C2016 Japanese Society of Chemotherapy and The Japanese Association for Infectious } \\
\text { Diseases. This manuscript version is made available under the CC-BY-NC-ND } 4.0 \\
\text { License. http://creativecommons.org/licenses/by-nc-nd/4.0/ } \\
\text { This is the accept manuscript version. The article has been published in final form at } \\
\text { https://doi.org/10.1016/j.jiac.2016.08.001 }\end{array}$ \\
\hline DOI & \begin{tabular}{l}
$10.1016 / j . j i a c .2016 .08 .001$ \\
\hline
\end{tabular} \\
\hline
\end{tabular}

Self-Archiving by Author(s)

Placed on: Osaka City University

$\mathrm{KOH} \mathrm{H}$, et al. (2016). Combinational approach using in situ hybridization targeting $23 \mathrm{~S}$ ribosomal RNA genes and blood cultures for bacterial identification in patients with neutropenia and fever. Journal of Infection and Chemotherapy: Official Journal of the Japan Society of Chemotherapy. 22, 697-703. 


\title{
Source of Funding
}

None

\author{
Institutions: ${ }^{1}$ Hematology, Graduate School of Medicine, Osaka City University, Osaka, Japan \\ ${ }^{2}$ Research and Development Center, Fuso Pharmaceutical Industries, Ltd., Osaka, \\ Japan
}

\section{ORIGINAL ARTICLE \\ Combinational approach using in situ hybridization targeting 23S ribosomal RNA genes and blood cultures for bacterial identification in patients with neutropenia and fever}

\author{
Correspondence: Hideo Koh, M.D., Ph.D. \\ Hematology, Graduate School of Medicine, Osaka City University, \\ 1-4-3, Asahi-machi, Abeno-ku, Osaka 545-8585, Japan \\ Phone: +81-6-6645-3881, Fax: +81-6-6646-3880 \\ E-mail: hide_koh@med.osaka-cu.ac.jp \\ None
}


RUNNING TITLE: Combination of in situ hybridization targeting 23S ribosomal RNA genes and blood culture for febrile neutropenia

Abstract: 250 words, Text: 2977 words 


\begin{abstract}
Background: A new 23S ribosomal RNA genes-targeted in situ hybridization (ISH) probe to detect global bacterial genomic DNA (59 species from 35 genera; referred to as the GB probe) phagocytized in leukocytes was recently developed. This method provided early and direct evidence of bacterial infection with high sensitivity and specificity in spontaneous bacterial peritonitis ascites. However, the utility of this method in febrile neutropenia (FN) is unknown.

Methods: We prospectively evaluated the utility of the ISH approach using the GB probe and previously reported probes in patients with neutropenia and fever undergoing chemotherapy at our institution between June 2011 and July 2013. Blood samples for culture analysis and ISH tests were collected simultaneously at the onset of fever; the latter were performed repeatedly.

Results: Fifty febrile episodes were evaluated. In 24 episodes of fever of unknown origin and 15 episodes of local infection (all negative for blood cultures), ISH tests identified causal bacteria in $21 \%$ and $13 \%$ of cases, respectively, at the onset of fever. In seven sepsis cases (all positive for blood culture), positive ISH test results at fever onset were achieved in $71 \%$; for two patients with neutrophil counts of $0 / \mu 1$ and $171 / \mu 1$, respectively, negative results were obtained.

Conclusions: This new ISH approach could prove useful for early detection of bacteria in patients with neutropenia and blood culture-negative, with fever of unknown etiology after chemotherapy. Using this method in combination with blood culture, even in cases with extremely low neutrophil counts, might contribute to better management of FN.
\end{abstract}

Key words: febrile neutropenia; bacterial identification; in situ hybridization; 23S ribosomal RNA genes; blood cultures 


\section{Introduction}

Despite recent advances in preventive intervention for infections, febrile neutropenia (FN) remains a common and important complication during intensive chemotherapy in patients with cancer, and particularly those with hematological disorders. Due to poor positive rates of the diagnostic gold standard (blood cultures with approximately $20 \%$ [1]), a fever-driven approach using anti-pseudomonal $\beta$-lactam agents is widely accepted in the management of FN [2]. However, this method results in overuse of antibiotics, increased side effects or costs, and induction of drug-resistance in bacteria. Optimizing FN management requires the identification of causal bacteria, which remains very challenging.

Several available diagnostic tools such as the detection of serum biomarkers (e.g. procalcitonin (PCT), interleukin (IL)-6, and IL-8) [3-5], polymerase chain reaction (PCR) [6,7], or mass spectrometry [8,9] could improve the management of FN. Although PCR analysis and mass spectrometry have the advantage of obtaining direct evidence of bacteria, the former could be susceptible to contamination with bacterial DNA [10-14], whereas the latter demonstrates insufficient diagnostic accuracy. However, both methods might be useful for identifying causal bacteria from positive blood culture samples [7-9]. However, a strategy based on these tools has not been standardized for the management of FN.

Recently, Enomoto et al. reported a new in situ hybridization (ISH) method that detects global bacterial DNA (59 species of 35 genera) in leukocytes, and achieved positive results in 10 of 11 ascites samples from patients with spontaneous bacterial peritonitis (SBP); all other (40) ascites samples from non-SBP patients were negative, demonstrating high sensitivity (91\%) and specificity (100\%) [15]. Notably, ISH tests were positive in seven SBP patients with negative 
culture results, and these tests were effective in samples with low concentrations of leukocytes $(100 / \mu 1)$. In addition, ISH test results were obtained within one day, which is consistent with those observed for septic blood samples. These data suggest that this test could also be useful for obtaining direct evidence of bacteria in patients with FN. To our knowledge, the utility of this method in FN has not been investigated.

Therefore, we prospectively examined the utility of this new ISH method, together with previous methods [16-18], in patients with hematological disorders who developed neutropenia and fever after chemotherapy. We also evaluated if serum biomarkers such as PCT, IL-6, and IL-8 could provide additional insight for detection of bacterial infections.

\section{Patients and methods}

Study design

We conducted a prospective, single-center, observational study to investigate the utility of the ISH method, using the new global bacteria (GB) probe as well as previous ISH probes, (SA, SE, PA, EF and EK, Table 1) for detecting bacterial infections in patients with neutropenia and fever at our institution between June 2011 and July 2013. In addition, we assessed the utility of measuring serum PCT and 27 serum cytokines and chemokines (IL-1 $\beta$, IL-1 receptor antagonist, IL-2, IL-4, IL-5, IL-6, IL-7, IL-8, IL-9, IL-10, IL-12, IL-13, IL-15, IL-17, Eotaxin, FGF basic, G-CSF, GM-CSF, IFN- $\gamma$, IP-10, MCP-1, MIP- $1 \alpha$, MIP-1 $\beta$, PDGF- $\beta \beta$, RANTES, TNF- $\alpha$, and VEGF) in patients with available samples (Supplementary Table 1 and 2).

This study was approved by the Human Subjects Review Committee at Osaka City University and we obtained signed informed consent from all patients in agreement with the Declaration of Helsinki. 


\section{Study subjects and sample collection}

The criteria for inclusion in the present study were as follows: patients who received chemotherapy, including a conditioning regimen for hematopoietic cell transplantation; patients who developed neutropenia and fever; patients who provided written informed consent. Neutropenia was defined as a neutrophil count of less than $500 / \mu 1$ or exceeding $500 / \mu 1$ with an expected decline to below $500 / \mu 1$. Fever was defined as an axillary temperature of $\geq 37.5{ }^{\circ} \mathrm{C}$ based on a single record from previous reports $[19,20]$. Blood samples for culture analysis and ISH tests were collected simultaneously at the onset of fever using aseptic technique. To repeatedly follow the ISH tests and examine the kinetics of serum cytokines and chemokines, the protocol was modified in January 2012. After that date, we performed the ISH tests and analyses of serum cytokines and chemokines at the time of neutrophil recovery and completion of antibiotics, in addition to the time of fever onset. If the result of the last follow-up ISH test was positive, additional ISH tests were recommended. Serum levels of PCT were also measured.

\section{Clinical evaluation and definitions for causes of febrile episodes}

As a rule, two sets of blood cultures were taken at the onset of neutropenic fever. Evaluations were conducted including physical examinations, blood tests, cultures of samples from suspected sites of infection, and imaging including computed tomography. Clinical efficacy was defined as defervescence for at least 48 hours, which was also assessed at 72 hours, at day 7 , and at the completion of intravenous antibiotic therapy, regardless of the addition of other antibiotics or antifungals, or changes in antibiotics used.

We defined the diagnostic categories of fever of unknown origin (FUO), local infection, and 
sepsis according to the modified criteria applicable in patients with FN [19-21]. Bacteremia by coagulase negative staphylococcus (CNS) was identified after obtaining at least two isolations of CNS with identical antibiograms, taken from different sites [3]. Drug fever was defined as previously reported [24]. Classification of febrile episodes was reviewed by two independent investigators and a final diagnosis was determined.

Detection of bacterial DNA by ISH using the GB probe and previous ISH probes (SA, SE, PA, EF, and $E K)$

All bacteria have 23S ribosomal RNA (rRNA) genes; therefore, a novel cDNA probe using the 23S rRNA genes, "GB probe" was developed to detect genomic DNA of causal bacteria. The GB probe consisted of plural cDNA fragments corresponding to the 23S rRNA genes of various bacteria, and successfully detected the genomic DNA of 59 bacterial species, belonging to 35 genera, that were tested (however, the GB probe could have the potential to detect other bacterial species) $[10,15]$. All bacterial species detectable by SA, SE, PA, EF and EK probes are included in the GB probe (Table 1). The details of ISH methods for detection of bacterial DNA have been described previously [10,15]. Briefly, $10 \mathrm{ml}$ of blood sample was aseptically drawn into a heparinized tube. Red blood cells were sedimented, and the supernatant (white blood cells) was collected. The white blood cells were then pelleted by centrifugation using phosphate buffered saline (PBS). Finally, the collected cell pellet was suspended at a concentration of $1-5 \times 10^{4}$ cells/ $\mu \mathrm{l}$ in PBS and as a rule, 5-10 $\mu \mathrm{l}$ of the cellular suspension was smeared on the glass slides. Digoxigenin-labeled probes were used for hybridization, and positive (intra-cellular purple-brown) signals were detected with nitro-blue tetrazolium and 5-bromo-4-chloro-3-indolyl phosphate. All assessments were performed by MIROKU Medical Laboratory Co., Ltd., 
independent of our institution.

\section{Measurement of serum biomarkers}

Serum levels of PCT and cytokines/chemokines were measured by an electrochemiluminescence immunoassay and the Bio-Plex Pro Cytokine Assay ${ }^{\circledR}$ system (Bio-Rad Laboratories, CA), respectively. Cut-off values of PCT and cytokines/chemokines, to determine positive results, were set at $0.5 \mathrm{ng} / \mathrm{ml}$ and those according to the manufacturer's instruction $[3,4,25]$, respectively.

Statistical analysis

For analysis of cytokines/chemokines kinetics, a paired t-test (at onset vs. at neutrophil recovery, or at onset vs. at the end of therapy) was applied. To evaluate the diagnostic performance of each variable, we used receiver operating characteristic (ROC) curves. All $P$ values and $95 \%$ CIs were determined by two-tailed tests, and a $P$ value of less than 0.05 was considered statistically significant. All statistical analyses were performed using IBM $^{\circledR}$ SPSS $^{\circledR}$ Statistics, version 22.0 and Graph Pad Prism ${ }^{\circledR}$ version 5.02 (Graph Pad Software Inc., San Diego, CA, USA).

\section{Results}

In 34 patients, 51 febrile events were examined in the study. Of these, we excluded one non-neutropenic fever and thus 50 febrile episodes were evaluated. The details of study participants and febrile episodes are shown in Table 2. Of the final diagnostic categories, approximately half included FUO and approximately $40 \%$ included clinically probable infections 
such as local infection. Local infections included six dental infections, three anal infections, one stomatitis, one pharyngitis, one colitis, one appendicitis, one cystitis, and one genital infection.

The results of the ISH tests, blood cultures, and serum PCT tests according to diagnostic category, are shown in Tables 3 and 4. The ISH tests were evaluated at the onset of fever in all 50 episodes. Those at neutrophil recovery were performed in 42 episodes and those at end of intravenous antibiotic therapy were performed in 21 episodes, because the timing of neutrophil recovery and the end of therapy were simultaneous in 21 episodes. Based on all 50 episodes, the positive ratio for this ISH test at fever onset was $36 \%(11 / 31)$ in the group with an absolute neutrophil count (ANC) less than $100 / \mu \mathrm{L}, 0 \%(0 / 12)$ in the group with an ANC of $100-500 / \mu \mathrm{L}$, and $14 \%(1 / 7)$ in the group with an ANC of greater than $500 / \mu \mathrm{L}$. In seven sepsis cases (all positive for blood cultures), positive results based on ISH and PCT tests at fever onset were observed in $71 \%$ and $43 \%$ of cases, respectively. In 15 cases of local infection, ISH and PCT positivity rates at fever onset were $13 \%$ and $25 \%$, respectively, and in 24 cases of FUO, ISH and PCT positivity rates at fever onset were $21 \%$ and $4 \%$, respectively; all cases were negative for blood culture. For ISH tests performed at the end of therapy or for additional evaluations, positive results were obtained in approximately $20-50 \%$ of cases. Of these 12 cases with positive results, invasive procedures were performed in six cases, one to several days before the ISH tests, and included bone marrow aspiration $(n=4)$ and insertion of a central venous catheter $(n=2)$.

In 36 patients with available blood samples, we investigated the serum level kinetics of 27 cytokines and chemokines during follow-up of febrile episodes and calculated the area under the curve (AUC) by employing receiver operating characteristic (ROC) analyses for these values for the detection of sepsis or bacterial infection (Supplementary Table 1 and 2). With reference to an AUC of 0.7 [26], we chose five markers including IL-6 (AUC of 0.789 for sepsis; 0.594 for 
bacterial infection), IL-8 (0.844; 0.651), MCP-1 (0.703; 0.600), MIP-1 $\alpha$ (0.602;0.702), and MIP-1 $\beta(0.898 ; 0.660)$ (Supplementary Table 2). Based on these analyses, we examined if these five markers could provide additional information, to results obtained from ISH tests, for diagnosing or monitoring bacterial infections in patients with local infection or FUO (Table 5). Information from both the ISH tests and kinetic analysis of IL-6 levels corresponded to clinical course in several patients (Table 5 and Figure). In addition, for each local infection $(\mathrm{n}=11)$ and FUO ( $\mathrm{n}=17$ ) groups, most of these biomarker levels (including 95\% CI) of the patients with negative results based on the ISH tests at the onset of febrile episodes were higher than those of each patient with positive result (Table 5).

\section{Discussion}

In the present study, we demonstrated that the new ISH test that uses a GB probe provides early direct evidence of bacterial infections in patients with neutropenia who are blood culture-negative, with fever of unknown etiology after chemotherapy. In addition, we found that ISH tests, using both GB and previously reported probes, detected approximately $20 \%$ blood culture-undetectable bacteremia of the causes of FUO.

PCR-based analysis [6,7] or mass spectrometry [8,9] is useful for identifying causal bacteria from samples such as positive blood cultures. However, particularly for PCR, there are disadvantages such as contamination of bacterial DNA (e.g. Taq-polymerases or reagents for DNA extraction procedures) [10-14], indicating that these methods require further standardization. In addition, serum biomarkers including PCT and IL-6 might not be useful in patients with FN, compared to those in non-neutropenic sepsis patients, because the levels of these markers could trend lower in neutropenic patients [27], probably due to 
chemotherapy-induced cytopenia. In fact, we observed that the levels of cytokines and chemokines such as IL-6 and IL-8 were elevated in patients with negative ISH test results at the onset of febrile episodes, compared to those in patients with positive results (Table 5). Therefore, detection of cytokines or chemokines as a single marker was not useful for detecting bacterial infections. However, the kinetics of serum IL-6 levels from the onset of the febrile episode to the end of therapy appeared to reflect infection activity in each individual case (Table 5 and Figure 1). Thus, the combined use of ISH methods and IL-6 determination could be more useful for FN management.

Several clinical studies have reported excellent diagnostic performance using ISH methods with high sensitivity and specificity $[15,17,18]$. Two previous clinical studies examined the utility of the ISH method for diagnosis of sepsis, and showed that the ISH method was four times more sensitive than blood culturing for the detection of causal bacteria [17,18]. In addition, these studies demonstrated that the ISH method and blood culturing identified the same causative bacteria. Recently, Enomoto et al. reported that this ISH method, with new and existing probes, could be used to obtain early direct evidence of causal bacteria from ascites samples with high sensitivity $(91 \%)$ and specificity $(100 \%)$ in patients with SBP (there were no false positive results in 40 non-SBP samples) [15]. This excellent specificity data, that is false positive rate of zero, could be explained by the fact that the ISH method detects the genomic DNA of bacteria phagocytized by neutrophils and macrophages and existing only in these cells.

In contrast, our data showed that the species of bacteria isolated from blood cultures did not necessarily correspond to the results of the ISH tests (Table 4). This suggests some important facts. Considering the previously mentioned excellent diagnostic performance of ISH tests, the positive ISH results in this study were most likely true positives. More specifically, the ISH tests 
provided information on multiple bacterial infections in patients with FN (Table 4). It was previously reported that this ISH method was effective with low leukocyte counts $(100 / \mu 1)$ $[15,17,18]$. However, two patients diagnosed with sepsis with neutrophil counts of $0 / \mu 1$ and 171/ $\mu 1$, showed negative results based on ISH tests (Table 4). Therefore, low neutrophil counts can decrease the sensitivity of ISH tests. In addition, the ability of this method to detect causal bacteria depends on the phagocytic activity of leukocytes [15]. Thus, inconsistent results might be caused by low neutrophil counts or decreased phagocytic activity of leukocytes because of chemotherapy. Another important point is that the diagnostic value of the ISH method needs to be assessed in the clinical context of the patient [28]; from this viewpoint, the results obtained herein seem reasonable (Table 4, Figure 1). Therefore, it should be considered that both blood culture and ISH test results could be true in patients with FN. However, the exact diagnostic performance including the rate of false positivity for the ISH test has not been established in FN. Further large-scale study is warranted to confirm the diagnostic utility of this ISH method in FN.

Previous studies reported other advantages for the ISH method based on existing probes as follows. The results were not affected by contamination or antibiotic treatment, because in contrast to the PCR method, this method does not amplify the amount of bacteria and detects bacterial DNA in the leukocytes after aseptic collection of leukocytes alone $[15,17,18]$. These advantages were also observed in the present study. In addition, the GB probe covers the majority of important bacterial strains in neutropenic patients, including Staphylococcus aureus, Enterococcus species, and Pseudomonas aeruginosa [2] (Table 1). Based on these observations, we postulate that the positive results observed in patients with FUO or local infection most likely were true positives, and the "negative" results were most likely true negatives. Therefore, the negative ISH result in local infection could provide the information that the infection does not 
spread systemically, although that might be caused by a false negative or bacteria that are not covered by the GB probe.

There are several limitations of the present study. First, we cannot accurately determine whether positive results based on the ISH method are indicative of active infection or are due to the detection of residual DNA of killed bacteria, especially when antibiotics are used. However, similar to blood cultures, we could assess active infection based on clinical signs or symptoms and inflammatory biomarkers including IL-6. Second, in blood culture-positive cases, positive ISH results were obtained in $71 \%$ of cases; two patients with neutrophil counts of $0 / \mu 1$ and $171 / \mu 1$ showed negative ISH results. This suggests that the ability of the ISH tests to detect causal bacteria might be diminished in cases of low leukocyte counts due to chemotherapy. However, the combined use of blood cultures and serum markers such PCT or IL-6 could compensate for this disadvantage. Third, the ISH tests showed positive results at or after the end of antibiotic therapy in more patients than expected. This suggests that the ISH test might not be useful for determining the appropriate endpoint for antibiotic therapy. However, this might be explained partly by detection of DNA from previously phagocytized and digested bacteria or blood culture-undetectable bacteremia by indigenous skin bacteria after invasive procedures such as bone marrow aspiration. Therefore, these positive results were most likely true positives, although these could have included false positives or results of contamination. A previous clinical trial demonstrated positive ISH results in patients with intravascular devices, and transient bacteremia was considered a possible explanation for this [17]. This disadvantage could be addressed by assessing clinical signs or symptoms and serum biomarkers such as pro-inflammatory cytokines. Conversely, the ability to obtain direct evidence of bacteria at the onset of FN is a strong point for this test. In addition, when a patient is in the recovery phase 
from chemotherapy-induced neutropenia, and has a fever of unknown etiology, a negative ISH test result might prompt changes from intravenous broad-spectrum antibiotics to oral antibiotics including quinolones, or earlier cessation of antibiotics.

Taken together, this new ISH method provides more information on causal bacteria in patients with neutropenia and fever during chemotherapy than blood culture. Combined use of these tests and additional information obtained from serum biomarker levels including PCT and IL-6 might contribute to better management of FN. Future study is needed to validate the clinical utility of this combinational approach for FN.

\section{Conflict of interest}

AM and SI are employees of Fuso Pharmaceutical Industries. All other authors have no conflicts of interest to declare.

\section{Acknowledgment}

We thank Kiyoko Tamai (MIROKU Medical Laboratory Co., Ltd.) for performing ISH tests assessments. 


\section{References}

1. Klastersky J, Ameye L, Maertens J, Georgala A, Muanza F, Aoun M, et al. Bacteraemia in febrile neutropenic cancer patients. Int J Antimicrob Agents 2007;30(Sup 1): S51-59.

2. Freifeld AG, Bow EJ, Sepkowitz KA, Boeckh MJ, Ito JI, Mullen CA, et al. Clinical practice guideline for the use of antimicrobial agents in neutropenic patients with cancer: 2010 update by the infectious diseases society of america. Clin Infect Dis 2011;52:e56-93.

3. Giamarellou H, Giamarellos-Bourboulis EJ, Repoussis P, Galani L, Anagnostopoulos N, Grecka P, et al. Potential use of procalcitonin as a diagnostic criterion in febrile neutropenia: experience from a multicentre study. Clin Microbiol Infect 2004;10:628-33.

4. Jimeno A, García-Velasco A, del Val O, González-Billalabeitia E, Hernando S, Hernández R, et al. Assessment of procalcitonin as a diagnostic and prognostic marker in patients with solid tumors and febrile neutropenia. Cancer 2004;100:2462-9.

5. Urbonas V, Eidukaitè A, Tamulienè I. The diagnostic value of interleukin-6 and interleukin-8 for early prediction of bacteremia and sepsis in children with febrile neutropenia and cancer. J Pediatr Hematol Oncol 2012;34:122-7.

6. Lamoth F, Jaton K, Prod'hom G, Senn L, Bille J, Calandra T, et al. Multiplex blood PCR in combination with blood cultures for improvement of microbiological documentation of infection in febrile neutropenia. J Clin Microbiol 2010;48:3510-6.

7. Shachor-Meyouhas Y, Sprecher H, Moscoviz D, Zaidman I, Haimi M, Kassis I. Molecular-based diagnosis of bacteremia in the setting of fever with or without neutropenia in pediatric hematology-oncology patients. J Pediatr Hematol Oncol 2013;35:500-3.

8. Salvador F, Porte L, Durán L, Marcotti A, Pérez J, Thompson L, et al. Breakthrough bacteremia due to Clostridium tertium in a patient with neutropenic fever, and identification 
by MALDI-TOF mass spectrometry. Int J Infect Dis 2013;17:e1062-3.

9. Egli A, Osthoff M, Goldenberger D, Halter J, Schaub S, Steiger J, et al. Matrix-assisted laser desorption/ionization time-of-flight mass spectrometry (MALDI-TOF) directly from positive blood culture flasks allows rapid identification of bloodstream infections in immunosuppressed hosts. Transpl Infect Dis 2015;17:481-7.

10. Enomoto H, Inoue S, Matsuhisa A, Nishiguchi S. Diagnosis of spontaneous bacterial peritonitis and an in situ hybridization approach to detect an "unidentified" pathogen. Int $\mathbf{J}$ Hepatol 2014;2014:634617.

11. Corless CE, Guiver M, Borrow R, Edwards-Jones V, Kaczmarski EB, Fox AJ. Contamination and sensitivity issues with a real-time universal 16S rRNA PCR. J Clin Microbiol 2000;38:1747-52.

12. Philipp S, Huemer HP, Irschick EU, Gassner C. Obstacles of Multiplex Real-Time PCR for Bacterial 16S rDNA: Primer Specifity and DNA Decontamination of Taq Polymerase. Transfus Med Hemother 2010;37:21-28.

13. Evans GE, Murdoch DR, Anderson TP, Potter HC, George PM, Chambers ST. Contamination of Qiagen DNA extraction kits with Legionella DNA. J Clin Microbiol 2003;41:3452-3.

14. Tilburg JJ, Nabuurs-Franssen MH, van Hannen EJ, Horrevorts AM, Melchers WJ, Klaassen CH. Contamination of commercial PCR master mix with DNA from Coxiella burnetii. J Clin Microbiol 2010;48:4634-5.

15. Enomoto H, Inoue S, Matsuhisa A, Aizawa N, Imanishi H, Saito M, et al. Development of a new in situ hybridization method for the detection of global bacterial DNA to provide early evidence of a bacterial infection in spontaneous bacterial peritonitis. J Hepatol 2012;56:85-94. 
16. Matsuhisa A, Saito Y, Sakamoto Y, Keshi H, Ueyama H, Aikawa Y, et al. Detection of bacteria in phagocyte-smears from septicemia-suspected blood by in situ hybridization using biotinylated probes. Microbiol Immunol 1994;38:511-7.

17. Shimada J, Hayashi I, Inamatsu T, Ishida M, Iwai S, Kamidono S, et al. Clinical trial of in-situ hybridization method for the rapid diagnosis of sepsis. J Infect Chemother 1999;5:21-31.

18. Kudo M, Matsuo Y, Nakasendo A, Inoue S, Goto H, Tsukiji J, et al. Potential clinical benefit of the in situ hybridization method for the diagnosis of sepsis. J Infect Chemother 2009;15:23-6.

19. Masaoka T. Evidence-based recommendations for antimicrobial use in febrile neutropenia in Japan: executive summary. Clin Infect Dis 2004;39(Sup 1):S49-52.

20. Tamura K, Imajo K, Akiyama N, Suzuki K, Urabe A, Ohyashiki K, et al. Randomized trial of cefepime monotherapy or cefepime in combination with amikacin as empirical therapy for febrile neutropenia. Clin Infect Dis 2004;39(Sup 1):S15-24.

21. From the Immunocompromised Host Society. The design, analysis, and reporting of clinical trials on the empirical antibiotic management of the neutropenic patient. Report of a consensus panel. J Infect Dis 1990;161:397-401.

22. Members of the American college of chest physicians/society of critical care medicine consensus conference committee. American College of Chest Physicians/Society of Critical Care Medicine Consensus Conference: definitions for sepsis and organ failure and guidelines for the use of innovative therapies in sepsis. Crit Care Med 1992;20:864-874.

23. Aimoto M, Koh H, Katayama T, Okamura H, Yoshimura T, Koh S, et al. Diagnostic performance of serum high-sensitivity procalcitonin and serum C-reactive protein tests for 
detecting bacterial infection in febrile neutropenia. Infection. 2014;42:971-9.

24. Patel RA, Gallagher JC. Drug fever. Pharmacotherapy 2010;30:57-69.

25. Chapman P, Reyes C, Gupta V: Normal physiological levels of human cytokines using Bio-Plex Pro ${ }^{\mathrm{TM}}$ cytokine assays. Bio-Plex ${ }^{\circledR}$ suspension array system. [pdf] Available at: < http://www.biorad.com/webroot/web/pdf/lsr/literature/Bulletin_6029.pdf> [Accessed 20 Apr 2016].

26. Akobeng AK. Understanding diagnostic tests 3: Receiver operating characteristic curves. Acta Paediatr 2007;96:644-7.

27. Oberholzer A, Souza SM, Tschoeke SK, Oberholzer C, Abouhamze A, Pribble JP, et al. Plasma cytokine measurements augment prognostic scores as indicators of outcome in patients with severe sepsis. Shock 2005;23:488-93.

28. Peters RP, van Agtmael MA, Danner SA, Savelkoul PH, Vandenbroucke-Grauls CM. New developments in the diagnosis of bloodstream infections. Lancet Infect Dis 2004;4:751-60. 


\title{
Figure legends
}

Fig. 1. Clinical course and results of in situ hybridization (ISH) tests, blood cultures, and serum levels of interleukin-6 (IL-6) during follow-up of febrile episodes

\section{Case 1}

A case of local infection (dentalgia) (the identical case to Pt no.1 in Table 5)

\section{Case 2}

A case of fever of unknown origin (identical case to Pt no.3 in Table 5)

\author{
Abbreviations: CFPM, cefepime: FCZ, fluconazole; LVFX, levofloxacin; MEPM, meropenem; \\ PIPC/TAZ, piperacillin/tazobactam; WBC, white blood cell
}



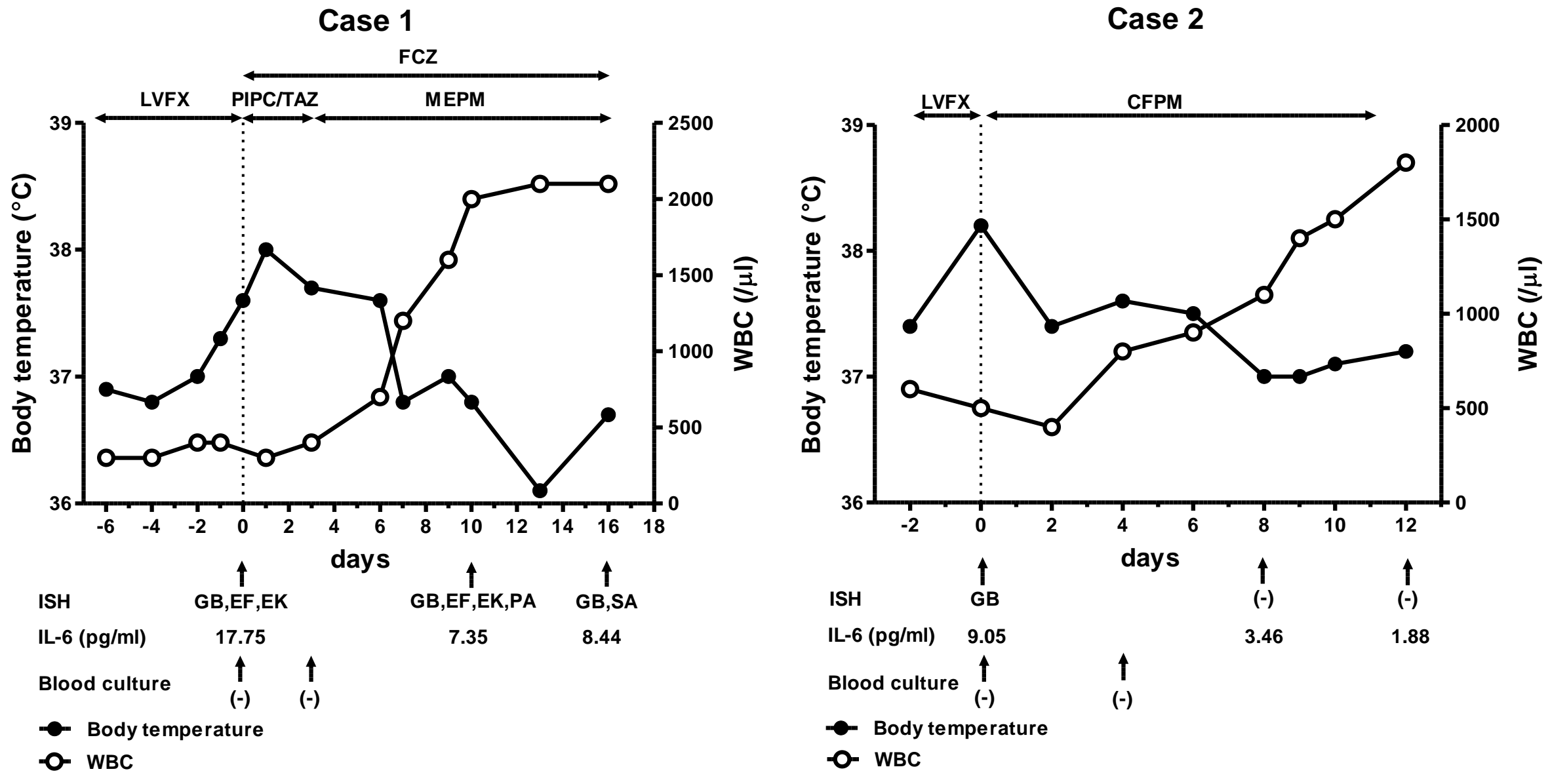
Table 1. Fifty-nine bacterial strains targeted by the GB probe and seven by the previous probes for use in in situ hybridization

\begin{tabular}{|c|c|c|}
\hline Probe & Genus & Species \\
\hline \multirow[t]{35}{*}{ GB } & Achromobacter & xylosoxidans \\
\hline & Acinetobacter & calcoaceticus \\
\hline & Bacillus & cereus \\
\hline & Bacteroides & fragilis \\
\hline & & ovatus \\
\hline & Brevundimonas & diminuta \\
\hline & Burkholderia & cepacia \\
\hline & Citrobacter & koseri \\
\hline & Clostridium & perfringens \\
\hline & Corynebacterium & diphtheriae \\
\hline & & pseudodiphteritcum \\
\hline & & jeikeium \\
\hline & Edwerdsiella & tarda \\
\hline & Eggerthella & lenta \\
\hline & Enterobacter & cloacae \\
\hline & & sakazakii \\
\hline & & aerogenes \\
\hline & & gergoviae \\
\hline & Enterococcus & faecalis \\
\hline & & faecium \\
\hline & & avium \\
\hline & Escherichia & coli \\
\hline & Fusobacterium & nucleatum \\
\hline & & necrophorum \\
\hline & Haemophilus & influenzae \\
\hline & Hafnia & alvei \\
\hline & Klebsiella & pneumoniae \\
\hline & & aerogenes \\
\hline & & oxytoca \\
\hline & Kluyvera & intermedia \\
\hline & Lactobacillus & fermentum \\
\hline & & acidophilus \\
\hline & Micrococcus & luteus \\
\hline & Morganella & morganii \\
\hline & Pantoea & agglomerans \\
\hline
\end{tabular}




\begin{tabular}{|c|c|}
\hline Peptoniphilus & asaccharolyticus \\
\hline Porphyromonas & asaccharolytica \\
\hline Propionibacterium & acnes \\
\hline Proteus & $\begin{array}{l}\text { vulgaris } \\
\text { mirabilis }\end{array}$ \\
\hline Providencia & $\begin{array}{l}\text { rettgeri } \\
\text { alcalifaciens } \\
\text { stuartii }\end{array}$ \\
\hline Pseudomonas & $\begin{array}{l}\text { aeruginosa } \\
\text { fluorescens } \\
\text { putida }\end{array}$ \\
\hline Raoultella & $\begin{array}{l}\text { terrigena } \\
\text { planticola }\end{array}$ \\
\hline Salmonella & enterica \\
\hline Serratia & $\begin{array}{l}\text { marcescens } \\
\text { liquefaciens }\end{array}$ \\
\hline Staphylococcus & $\begin{array}{l}\text { aureus } \\
\text { epidermidis }\end{array}$ \\
\hline Stenotrophomonas & maltophilia \\
\hline Streptococcus & $\begin{array}{l}\text { pneumoniae } \\
\text { sanguinis } \\
\text { pyogenes } \\
\text { agalactiae } \\
\text { salivarius }\end{array}$ \\
\hline Staphylococcus & aureus \\
\hline Staphylococcus & epidermidis \\
\hline Pseudomonas & aeruginosa \\
\hline Enterococcus & faecalis \\
\hline Escherichia & coli \\
\hline Enterobacter & cloacae \\
\hline Klebsiella & pneumoniae \\
\hline
\end{tabular}


Table 2. Patient characteristics and details of febrile episodes

\begin{tabular}{lc}
\hline Patients, $\mathrm{n}$ & 34 \\
\hline Median age (range), years & $42.5(19-70)$ \\
Gender, n (\%) & \\
$\quad$ male & $18(52.9)$ \\
female & $16(47.1)$ \\
Primary disease, n (\%) & \\
Acute myeloid leukemia & $11(32.4)$ \\
Acute lymphoblastic leukemia & $10(29.4)$ \\
Non-Hodgkin lymphoma & $8(23.5)$ \\
Myelodysplastic syndrome & $3(8.8)$ \\
Others* & $2(5.9)$ \\
\hline
\end{tabular}

Febrile episode, $\mathrm{n}$
Treatment, $\mathrm{n}(\%)$
Chemotherapy
Autologous hematopoietic stem cell transplantation
Allogeneic hematopoietic stem cell transplantation
Others $\dagger$
White blood cell count at enrollment $(/ \mu \mathrm{l})$, median (range)
Neutrophil count at enrollment $(/ \mu \mathrm{l})$, median (range)
Serum procalcitonin levels at onset of febrile neutropenia $(\mathrm{mg} / \mathrm{dl})$,
median (range)
50

Serum creatinine at onset of febrile neutropenia $(\mathrm{mg} / \mathrm{dl})$, median (range) $\quad 0.59(0.37-1.28)$ Use of G-CSF, n (\%)

Yes

No

$17(34.0)$

Oral quinolone prophylaxis

Yes

$40(80.0)$

No

$10(20.0)$

Antifungal prophylaxis

Fluconazole

$33(66.0)$

Oral voriconazole or itraconazole oral solution

$13(26.0)$

Others

$1(2.0)$

None

$3(6.0)$

Intravenous empirical or targeted antifungal therapy

Yes

No

$37(74.0)$

Duration of intravenous broad-spectrum antibiotic use (days), median

$10(4-51)$ 
(range)

Final diagnosis

Fever of unknown origin

Local infection

Sepsis

Others:

$4(7.5)$

Response at 72 hours of intravenous antibiotic therapy, \% (n/n) $40.0(20 / 50)$

Response at 7 days of intravenous antibiotic therapy $44.7(17 / 38)$

Response at end of intravenous antibiotic therapy

*Chronic myeloid leukemia blast crisis, $\mathrm{n}=1$; aplastic anemia, $\mathrm{n}=1$

$\dagger$ Cyclosporine plus anti-thymoglobulin, $\mathrm{n}=1$; imatinib, $\mathrm{n}=1$; none, $\mathrm{n}=1$

$\$$ All patients were diagnosed as having drug-induced fever 
Table 3. Number of positive cases based on in situ hybridization (ISH) method, blood cultures, or serum procalcitonin (PCT) test

\begin{tabular}{|c|c|c|c|c|c|c|}
\hline & $\begin{array}{l}\text { ISH at onset } \\
(\mathrm{n}=50)\end{array}$ & $\begin{array}{l}\text { Blood culture } \\
\text { at onset }(\mathrm{n}= \\
50)\end{array}$ & $\begin{array}{l}\text { Serum PCT } \\
\text { at onset }(n= \\
46) \dagger\end{array}$ & $\begin{array}{l}\text { ISH at } \\
\text { neutrophil } \\
\text { recovery }(\mathrm{n}= \\
42)\end{array}$ & $\begin{array}{l}\text { ISH at EOT (n } \\
=21)\end{array}$ & $\begin{array}{l}\text { Additional } \\
\text { ISH after } \\
\text { EOT }(n=10)\end{array}$ \\
\hline Total $(\mathrm{n}=50)$ & $24 \%(12 / 50)$ & $14 \%(7 / 50)$ & $15 \%(7 / 46)$ & $26 \%(11 / 42)$ & $48 \%(10 / 21)$ & $20 \%(2 / 10)$ \\
\hline Sepsis $(\mathrm{n}=7), \%(\mathrm{n} / \mathrm{n})$ & $71 \%(5 / 7)$ & $100 \%(7 / 7)$ & $43 \%(3 / 7)$ & $67 \%(4 / 6)$ & $67 \%(4 / 6)$ & $0 \%(0 / 1)$ \\
\hline $\begin{array}{l}\text { Local infection }(\mathrm{n}=15) \\
\%(\mathrm{n} / \mathrm{n})\end{array}$ & $13 \%(2 / 15)$ & $0 \%(0 / 15)$ & $25 \%(3 / 12)$ & $25 \%(3 / 12)$ & $50 \%(2 / 4)$ & $0 \%(0 / 3)$ \\
\hline $\begin{array}{l}\text { Fever of unknown origin }(n= \\
24), \%(n / n)\end{array}$ & $21 \%(5 / 24)$ & $0 \%(0 / 24)$ & $4 \%(1 / 23)$ & $15 \%(3 / 20)$ & $22 \%(2 / 9)$ & $40 \%(2 / 5)$ \\
\hline Others: $(\mathrm{n}=4), \%(\mathrm{n} / \mathrm{n})$ & $0 \%(0 / 4)$ & $0 \%(0 / 4)$ & $0 \%(0 / 4)$ & $25 \%(1 / 4)$ & $100 \%(2 / 2)$ & $0 \%(0 / 1)$ \\
\hline
\end{tabular}

*Abbreviations: EOT, end of intravenous antibiotic therapy

$\dagger$ The cut-off value of PCT to determine positivity was set at $0.5 \mathrm{ng} / \mathrm{ml}$. Four cases were not included because information was absent. $\$$ All patients were diagnosed as having drug-induced fever. 
Table 4. Details of positive cases based on in situ hybridization (ISH) or blood culture at onset of febrile neutropenia

\begin{tabular}{|c|c|c|c|c|c|c|c|c|c|c|c|}
\hline Pt no. & $\begin{array}{l}\text { Age/ } \\
\text { Sex }\end{array}$ & $\begin{array}{l}\text { WBC } \\
\text { counts } \\
(/ \mu \mathrm{l})\end{array}$ & Diagnosis & $\begin{array}{l}\text { PCT } \\
(\mathrm{ng} / \mathrm{ml})\end{array}$ & ISH at onset & $\begin{array}{l}\text { ISH at } \\
\text { neutrophil } \\
\text { recovery }\end{array}$ & $\begin{array}{l}\text { ISH at } \\
\text { EOT }\end{array}$ & $\begin{array}{l}\text { Additional } \\
\text { ISH after } \\
\text { EOT }\end{array}$ & $\begin{array}{l}\text { Response at } \\
72 \text { hours of } \\
\text { therapy }\end{array}$ & $\begin{array}{l}\text { Response at } \\
7 \text { days of } \\
\text { therapy }\end{array}$ & $\begin{array}{l}\text { Response } \\
\text { at EOT }\end{array}$ \\
\hline 1 & $39 / \mathrm{F}$ & 0 & $\begin{array}{l}\text { Sepsis } \\
\text { (Staphylococcus } \\
\text { epidermidis) }\end{array}$ & 0.12 & GB, EF, EK & GB & $\dagger \mathrm{GB}$ & Negative & No & No & Yes \\
\hline 2 & $35 / \mathrm{M}$ & 100 & $\begin{array}{l}\text { Sepsis } \\
\text { (Escherichia } \\
\text { coli) }\end{array}$ & 0.52 & GB, PA & GB & GB, EK & - & No & No & Yes \\
\hline 3 & $21 / \mathrm{F}$ & 100 & $\begin{array}{l}\text { Sepsis } \\
\text { (Streptococcus } \\
\text { intermedius) }\end{array}$ & 1.45 & GB, SE & Negative & $\dagger \mathrm{GB}, \mathrm{SA}$ & - & No & No & Yes \\
\hline 4 & $48 / \mathrm{M}$ & 100 & $\begin{array}{l}\text { Sepsis } \\
\text { (Streptococcus } \\
\text { oralis) }\end{array}$ & 0.46 & GB, EF, EK & $\mathrm{GB}, \mathrm{EF}$ & Negative & - & No & No & Yes \\
\hline 5 & $21 / \mathrm{F}$ & 0 & $\begin{array}{l}\text { Sepsis } \\
\text { (Streptococcus } \\
\text { haemolyticus) }\end{array}$ & 0.17 & $\mathrm{~GB}, \mathrm{PA}, \mathrm{EF}$ & Negative & Negative & - & No & No & No \\
\hline 6 & $32 / \mathrm{M}$ & 200 & $\begin{array}{l}\text { Sepsis } \\
\text { (Staphylococcus } \\
\text { epidermidis) }\end{array}$ & 0.54 & Negative & $\ddagger \mathrm{GB}, \mathrm{EK}$ & $\begin{array}{l}\dagger \mathrm{GB}, \mathrm{PA}, \\
\mathrm{EF}, \mathrm{EK}, \\
\mathrm{SA}, \mathrm{SE}\end{array}$ & - & No & Yes & Yes \\
\hline 7 & $40 / \mathrm{F}$ & 300 & $\begin{array}{l}\text { Sepsis } \\
\text { (Streptococcus } \\
\text { mitis) }\end{array}$ & 0.06 & Negative & - & - & - & Yes & Yes & Yes \\
\hline 8 & $22 / \mathrm{F}$ & 4600 & $\begin{array}{l}\text { Local infection } \\
\text { (pudendal pain) }\end{array}$ & - & GB & Negative & - & - & No & Yes & Yes \\
\hline 9 & $20 / \mathrm{F}$ & 400 & $\begin{array}{l}\text { Local infection } \\
\text { (dentalgia) }\end{array}$ & - & GB, EF, EK & $\begin{array}{l}\text { GB, } \\
\text { EK, PA, }\end{array}$ & $\dagger \mathrm{GB}, \mathrm{SA}$ & - & No & Yes & Yes \\
\hline 10 & $65 / \mathrm{M}$ & 500 & FUO & 0.10 & GB & Negative & Negative & - & No & Yes & Yes \\
\hline 11 & $22 / \mathrm{M}$ & 200 & FUO & 0.11 & EK & Negative & Negative & - & Yes & No & Yes \\
\hline 12 & 29/M & 400 & FUO & 0.09 & $\mathrm{~GB}, \mathrm{EF}$ & Negative & - & - & Yes & $\mathrm{NE}$ & Yes \\
\hline 13 & $61 / \mathrm{F}$ & 400 & FUO & 0.08 & EK & Negative & - & - & Yes & Yes & Yes \\
\hline 14 & 49/M & 100 & FUO & 1.65 & GB, EK & - & - & - & No & No & Yes \\
\hline
\end{tabular}


*Abbreviations: EOT, end of intravenous antibiotic therapy; FUO, fever of unknown origin †Invasive procedures were performed one to several days before ISH tests at EOT: central venous catheterization was performed in Pt no. 1 ( 3 days before the ISH test); bone marrow examination was performed in Pt no. 3 (1 day before), 6 ( 5 days before), and 9 (5 days before).

$\$$ Pt no. 6 presented with anal pain from 12 days after onset of fever until two days before the ISH test during neutrophil recovery. 
Table 5. Details of serum cytokine and chemokine kinetics according to positive or negative results based on in situ hybridization (ISH) tests at onset of febrile episodes in patients with local infection $(n=11)$ and fever of unknown origin $(n=$ 17)

\begin{tabular}{|c|c|c|c|c|c|c|c|c|c|c|}
\hline Pt no. & $\begin{array}{l}\text { WBC } \\
\text { counts } \\
(/ \mu l) ; \\
\text { median } \\
\text { (range) }\end{array}$ & Diagnosis & $\begin{array}{l}\text { ISH } \\
\text { at } \\
\text { onset }\end{array}$ & $\begin{array}{l}\text { PCT } \\
(\mathrm{ng} / \mathrm{ml}) ; \\
\text { median } \\
\text { (range) }\end{array}$ & & $\begin{array}{l}\mathrm{IL}-6(<9.00 \\
\mathrm{pg} / \mathrm{ml}) ; \\
\text { mean }(95 \% \\
\mathrm{CI})\end{array}$ & $\begin{array}{l}\mathrm{IL}-8(< \\
116.00 \\
\mathrm{pg} / \mathrm{ml}) ; \text { mean } \\
(95 \% \mathrm{CI})\end{array}$ & $\begin{array}{l}\text { MCP-1 }(< \\
48.00 \mathrm{pg} / \mathrm{ml}) \\
\text { mean }(95 \% \\
\mathrm{CI})\end{array}$ & $\begin{array}{l}\text { MIP-1 } \alpha(< \\
2.00 \mathrm{pg} / \mathrm{ml}) \\
\text { mean }(95 \% \\
\text { CI) }\end{array}$ & $\begin{array}{l}\text { MIP-1 } \beta(< \\
47.00 \mathrm{pg} / \mathrm{ml}) \\
\text { mean }(95 \% \\
\text { CI) }\end{array}$ \\
\hline \multirow[t]{3}{*}{1} & \multirow[t]{3}{*}{400} & \multirow{3}{*}{$\begin{array}{l}\text { Local } \\
\text { (dentalgia) }\end{array}$} & \multirow{3}{*}{$\begin{array}{l}\mathrm{GB}, \\
\mathrm{EF} \\
\mathrm{EK}\end{array}$} & \multirow[t]{3}{*}{ NA } & At onset & 17.75 & 28.00 & 39.30 & 0.98 & 48.85 \\
\hline & & & & & $\begin{array}{l}\text { At neutrophil } \\
\text { recovery }\end{array}$ & 7.35 & 27.00 & 20.81 & 2.72 & 76.40 \\
\hline & & & & & At EOT & 8.44 & 24.29 & 37.98 & 4.38 & 78.76 \\
\hline \multirow[t]{3}{*}{2} & \multirow[t]{3}{*}{4600} & \multirow{3}{*}{$\begin{array}{l}\text { Local } \\
\text { (pudendal } \\
\text { pain) }\end{array}$} & \multirow[t]{3}{*}{ GB } & \multirow[t]{3}{*}{ NA } & At onset & 4.85 & 0.62 & 17.25 & 8.98 & 40.19 \\
\hline & & & & & $\begin{array}{l}\text { At neutrophil } \\
\text { recovery }\end{array}$ & 0.00 & 1.88 & 10.84 & 9.32 & 25.45 \\
\hline & & & & & At EOT & - & - & - & - & - \\
\hline \multirow{4}{*}{$\begin{array}{l}\text { Negative } \\
\text { ISH group } \\
\text { of local } \\
\text { infection } \\
(n=9) \dagger\end{array}$} & \multirow{4}{*}{$\begin{array}{l}200 \\
(0-2400)\end{array}$} & \multirow[t]{4}{*}{ Local } & \multirow[t]{4}{*}{-} & \multirow{4}{*}{$\begin{array}{l}0.15 \\
(0.00- \\
10.38)\end{array}$} & At onset & 55.12 & 73.51 & 282.9 & 4.83 & 144.3 \\
\hline & & & & & & (3.19-10/.1 & $(1.56-145.5)$ & (63.98-501.8) & $(2.82-0.84)$ & $(13.21-2 / 5.5)$ \\
\hline & & & & & $\begin{array}{l}\text { At neutrophil } \\
\text { recovery }\end{array}$ & $\begin{array}{l}4.63 \\
(1.13-8.14)\end{array}$ & $\begin{array}{l}9.51 \\
(2.63-16.40)\end{array}$ & $\begin{array}{l}72.26 \\
(1.92-142.6)\end{array}$ & $\begin{array}{l}2.63 \\
(0.86-4.40)\end{array}$ & $\begin{array}{l}63.65 \\
(41.29-86.02)\end{array}$ \\
\hline & & & & & At EOT & $\begin{array}{l}3.18 \\
(0.75-5.61)\end{array}$ & $\begin{array}{l}9.49 \\
(2.62-16.36)\end{array}$ & $\begin{array}{l}31.14 \\
(14.53-47.75)\end{array}$ & $\begin{array}{l}2.92 \\
(1.06-4.77)\end{array}$ & $\begin{array}{l}60.58 \\
(37.13-84.03)\end{array}$ \\
\hline \multirow[t]{3}{*}{3} & \multirow[t]{3}{*}{500} & \multirow[t]{3}{*}{ FUO } & \multirow[t]{3}{*}{ GB } & \multirow[t]{3}{*}{0.10} & At onset & 9.05 & 12.86 & 22.52 & 1.90 & 153.62 \\
\hline & & & & & $\begin{array}{l}\text { At neutrophil } \\
\text { recovery }\end{array}$ & 3.46 & 10.99 & 14.94 & 1.99 & 174.95 \\
\hline & & & & & At EOT & 1.88 & 5.46 & 19.36 & 1.84 & 145.43 \\
\hline \multirow[t]{2}{*}{4} & \multirow[t]{2}{*}{200} & \multirow[t]{2}{*}{ FUO } & \multirow[t]{2}{*}{ EK } & \multirow[t]{2}{*}{0.11} & At onset & 7.85 & 26.21 & 47.37 & 2.14 & 33.20 \\
\hline & & & & & $\begin{array}{l}\text { At neutrophil } \\
\text { recovery }\end{array}$ & 0.26 & 2.10 & 4.46 & 0.62 & 2.60 \\
\hline
\end{tabular}




\begin{tabular}{|c|c|c|c|c|c|c|c|c|c|c|}
\hline \multirow{3}{*}{5} & \multirow{3}{*}{400} & \multirow{3}{*}{ FUO } & \multirow{3}{*}{ EK } & \multirow{3}{*}{0.08} & \multirow{3}{*}{$\begin{array}{l}\text { At EOT } \\
\text { At onset } \\
\text { At neutrophil } \\
\text { recovery }\end{array}$} & \multirow{2}{*}{$\begin{array}{l}6.29 \\
21.67\end{array}$} & \multirow{2}{*}{$\begin{array}{l}9.94 \\
26.23\end{array}$} & \multirow{2}{*}{$\begin{array}{l}18.84 \\
44.28\end{array}$} & \multirow{2}{*}{$\begin{array}{l}4.30 \\
1.39\end{array}$} & \multirow{2}{*}{$\begin{array}{l}94.11 \\
25.20\end{array}$} \\
\hline & & & & & & & & & & \\
\hline & & & & & & & 3.19 & 98.04 & 0.91 & 26.99 \\
\hline \multirow{4}{*}{$\begin{array}{l}\text { Negative } \\
\text { ISH group } \\
\text { of FUO (n } \\
=14) \dagger\end{array}$} & & & & & At EOT & - & - & - & - & - \\
\hline & \multirow[t]{3}{*}{$\begin{array}{l}450 \\
(100- \\
1200)\end{array}$} & \multirow[t]{3}{*}{ FUO } & \multirow[t]{3}{*}{-} & \multirow[t]{3}{*}{$\begin{array}{l}0.14 \\
(0.05- \\
0.35)\end{array}$} & At onset & $\begin{array}{l}31.75 \\
(14.61-48.9 \\
0)\end{array}$ & $\begin{array}{l}27.60 \\
(15.15-40.04)\end{array}$ & $\begin{array}{l}129.8 \\
(75.09-184.5)\end{array}$ & $\begin{array}{l}3.14 \\
(1.33-4.95)\end{array}$ & $\begin{array}{l}57.80 \\
(40.27-75.32)\end{array}$ \\
\hline & & & & & $\begin{array}{l}\text { At neutrophil } \\
\text { recovery }\end{array}$ & $\begin{array}{l}12.41 \\
(5.90-18.92 \\
)\end{array}$ & $\begin{array}{l}12.71 \\
(6.63-18.79)\end{array}$ & $\begin{array}{l}55.86 \\
(21.83-89.89)\end{array}$ & $\begin{array}{l}4.02 \\
(2.07-5.97)\end{array}$ & $\begin{array}{l}68.52 \\
(49.92-87.12)\end{array}$ \\
\hline & & & & & At EOT & $\begin{array}{l}9.87 \\
(5.14-14.60\end{array}$ & $\begin{array}{l}11.42 \\
(5.71-17.12)\end{array}$ & $\begin{array}{l}47.43 \\
(14.49-80.37)\end{array}$ & $\begin{array}{l}4.74 \\
(2.60-6.88)\end{array}$ & $\begin{array}{l}72.89 \\
(56.96-88.82)\end{array}$ \\
\hline
\end{tabular}

*Abbreviations: EOT, end of intravenous antibiotic therapy; FUO, fever of unknown origin; IL, interleukin; MCP-1, monocyte chemoattractant-1; MIP-1 $\alpha$, macrophage inflammatory protein- $1 \alpha$

$\dagger$ Both groups included all patients with negative results based on ISH tests at onset of febrile episodes. 
Supplementary Table 1. Kinetics of serum levels of 27 cytokines and chemokines during follow-up according to the diagnostic category of febrile episodes $(n=36)$

\begin{tabular}{|c|c|c|c|c|c|}
\hline & & \multicolumn{4}{|c|}{ Diagnosis } \\
\hline & & $\begin{array}{l}\text { Sepsis / septic shock } \\
n=4\end{array}$ & $\begin{array}{l}\text { Local infection } \\
n=11\end{array}$ & $\begin{array}{l}\text { FUO } \\
\mathbf{n}=\mathbf{1 7}\end{array}$ & $\begin{array}{l}\text { Others } \\
\mathrm{n}=4\end{array}$ \\
\hline \multicolumn{6}{|l|}{$\begin{array}{l}\text { Cytokines and } \\
\text { chemokines } \\
\text { (normal } \\
\text { reference } \\
\text { range }+, p g / m l)\end{array}$} \\
\hline \multirow[t]{3}{*}{$\mathrm{IL}-1 \beta(<0.70)$} & $\begin{array}{l}\text { At onset of febrile } \\
\text { episodes } \\
\text { mean (range) }\end{array}$ & $0.66(0.21-0.98)$ & $0.32(0.00-0.71)$ & $0.57(0.02-1.92)$ & $1.56(0.37-2.72)$ \\
\hline & $\begin{array}{l}\text { At neutrophil recovery } \\
\text { mean (range) } \\
P \text { value (vs. at onset) }\end{array}$ & $\begin{array}{l}0.82(0.39-1.24) \\
P=0.310\end{array}$ & $\begin{array}{l}0.41(0.04-1.34) \\
P=0.404\end{array}$ & $\begin{array}{l}0.64(0.14-1.82) \\
P=0.606\end{array}$ & $\begin{array}{l}0.82(0.07-1.46) \\
P=0.114\end{array}$ \\
\hline & $\begin{array}{l}\text { At EOT } \\
\text { mean (range) } \\
P \text { value (vs. at onset) }\end{array}$ & $\begin{array}{l}1.49(0.48-2.27) \\
P=0.087\end{array}$ & $\begin{array}{l}0.54(0.04-1.78) \\
P=0.192\end{array}$ & $\begin{array}{l}0.77(0.14-1.82) \\
P=0.154\end{array}$ & $\begin{array}{l}0.96(0.07-1.78) \\
P=0.224\end{array}$ \\
\hline \multirow[t]{3}{*}{$\begin{array}{l}\text { IL-1 receptor } \\
\text { antagonist } \\
(<665.00)\end{array}$} & $\begin{array}{l}\text { At onset of febrile } \\
\text { episodes } \\
\text { mean (range) }\end{array}$ & $69.90(0.00-124.20)$ & $43.47(0.00-262.75)$ & $60.14(0.00-578.59)$ & $130.55(44.36-221.87)$ \\
\hline & $\begin{array}{l}\text { At neutrophil recovery } \\
\text { mean (range) } \\
P \text { value (vs. at onset) }\end{array}$ & $\begin{array}{l}47.39(3.21-90.25) \\
P=0.299\end{array}$ & $\begin{array}{l}32.93(0.00-92.33) \\
P=0.705\end{array}$ & $\begin{array}{l}50.70(0.00-255.88) \\
P=0.699\end{array}$ & $\begin{array}{l}55.15(0.00-81.90) \\
P=0.180\end{array}$ \\
\hline & $\begin{array}{l}\text { At EOT } \\
\text { mean (range) } \\
P \text { value (vs. at onset) }\end{array}$ & $\begin{array}{l}77.84(9.62-119.98) \\
P=0.651\end{array}$ & $\begin{array}{l}38.73(0.00-130.14) \\
P=0.872\end{array}$ & $\begin{array}{l}58.51(0.00-255.88) \\
P=0.946\end{array}$ & $\begin{array}{l}58.95(0.00-130.14) \\
P=0.178\end{array}$ \\
\hline IL-2 (<90.00) & $\begin{array}{l}\text { At onset of febrile } \\
\text { episodes } \\
\text { mean (range) }\end{array}$ & $4.58(0.00-18.33)$ & $1.20(0.00-10.53)$ & $0.87(0.00-14.82)$ & $3.13(0.00-6.53)$ \\
\hline
\end{tabular}




\begin{tabular}{|c|c|c|c|c|c|}
\hline & At neutrophil recovery & $3.87(0.00-15.46)$ & $0.91(0.00-9.99)$ & $0.78(0.00-8.05)$ & $0.00(0.00-0.00)$ \\
\hline & mean (range) & $P=0.391$ & $P=0.258$ & $P=0.934$ & $P=0.107$ \\
\hline & $P$ value (vs. at onset) & & & & \\
\hline & At EOT & $4.30(0.00-12.92)$ & $1.01(0.00-6.69)$ & $0.83(0.00-8.05)$ & $1.10(0.00-4.39)$ \\
\hline & mean (range) & $P=0.889$ & $P=0.756$ & $P=0.967$ & $P=0.372$ \\
\hline & $P$ value (vs. at onset) & & & & \\
\hline IL-4 (<3.00) & $\begin{array}{l}\text { At onset of febrile } \\
\text { episodes } \\
\text { mean (range) }\end{array}$ & $1.29(0.35-2.56)$ & $0.53(0.00-1.14)$ & $0.80(0.00-2.55)$ & $2.70(1.22-4.08)$ \\
\hline & At neutrophil recovery & $1.69(0.66-2.51)$ & $1.10(0.27-1.98)$ & $1.77(0.08-4.58)$ & $1.49(0.46-2.41)$ \\
\hline & $\begin{array}{l}\text { mean (range) } \\
P \text { value (vs. at onset) }\end{array}$ & $P=0.180$ & $P=0.016$ & $P=0.029$ & $P=0.156$ \\
\hline & At EOT & $2.43(0.99-3.21)$ & $1.38(0.00-2.63)$ & $2.02(0.35-4.58)$ & $1.78(0.46-2.63)$ \\
\hline & mean (range) & $P=0.113$ & $P=0.015$ & $P=0.004$ & $P=0.304$ \\
\hline & $P$ value (vs. at onset) & & & & \\
\hline IL-5 (<7.00) & $\begin{array}{l}\text { At onset of febrile } \\
\text { episodes } \\
\text { mean (range) }\end{array}$ & $2.35(0.45-6.45)$ & $0.70(0.00-2.71)$ & $3.50(0.00-15.41)$ & $2.78(1.04-4.96)$ \\
\hline & At neutrophil recovery & $3.35(0.48-6.99)$ & $1.11(0.08-2.77)$ & $2.10(0.08-5.09)$ & $1.97(0.75-3.45)$ \\
\hline & $\begin{array}{l}\text { mean (range) } \\
P \text { value (vs at onset) }\end{array}$ & $P=0.213$ & $P=0.020$ & $P=0.264$ & $P=0.258$ \\
\hline & At EOT & $4.23(0.48-6.13)$ & $1.23(0.08-3.50)$ & $2.81(0.29-11.23)$ & $2.12(0.75-3.45)$ \\
\hline & mean (range) & $P=0.207$ & $P=0.023$ & $P=0.617$ & $P=0.283$ \\
\hline & $P$ value (vs. at onset) & & & & \\
\hline IL-6 $(<9.00)$ & $\begin{array}{l}\text { At onset of febrile } \\
\text { episodes } \\
\text { mean (range) }\end{array}$ & $155.33(19.77-435.55)$ & $47.16(1.53-182.88)$ & $28.42(0.49-105.73)$ & $34.58(1.39-65.99)$ \\
\hline & At neutrophil recovery & $6.75(1.67-13.38)$ & $4.46(0.00-13.32)$ & $10.71(0.26-37.96)$ & $4.67(0.96-7.35)$ \\
\hline & mean (range) & $P=0.215$ & $P=0.055$ & $P=0.018$ & $P=0.201$ \\
\hline & $P$ value (vs. at onset) & & $337(000-1055)$ & $888(188-2868)$ & \\
\hline & mean (range) & $P=0.213$ & $P=0.048$ & $P=0.009$ & $P=0.205$ \\
\hline & $P$ value (vs. at onset) & & & & \\
\hline IL-7 $(<13.00)$ & At onset of febrile & $4.08(2.47-6.06)$ & $13.69(1.77-124.97)$ & $13.14(0.00-97.68)$ & $13.65(3.39-24.40)$ \\
\hline & $\begin{array}{l}\text { episodes } \\
\text { mean (range) }\end{array}$ & & & & \\
\hline
\end{tabular}




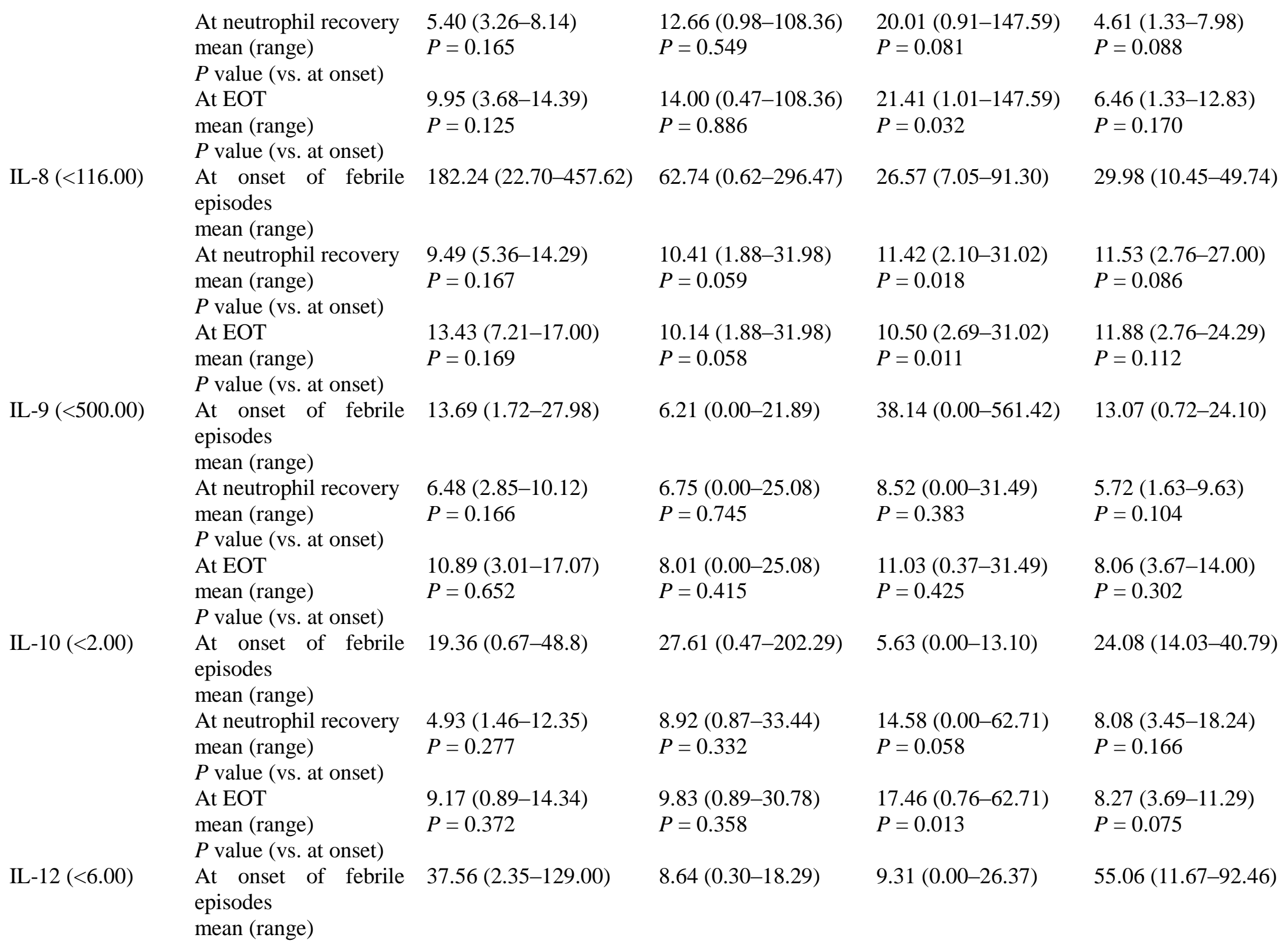


At neutrophil recovery mean (range)

$P$ value (vs. at onset)

At EOT

mean (range)

$P$ value (vs. at onset)

IL-13 $(<9.00)$

episodes

mean (range)

At neutrophil recovery

mean (range)

$P$ value (vs. at onset)

At EOT

$P$ value (vs. at onset)

IL-15 $(<5.00)$

IL-17 $(<31.00)$

Eotaxin $(<39.00)$

episodes

mean (range)

At neutrophil recovery

mean (range)

$P$ value (vs. at onset)

At EOT

mean (range)

$P$ value (vs. at onset) episodes

mean (range)

At neutrophil recovery

mean (range)

$P$ value (vs. at onset)

At EOT

$P$ value (vs. at onset) mean (range)

34.48 (3.39-104.42)

$P=0.742$

$46.66(5.64-98.65)$

$P=0.587$

$0.62(0.00-1.25)$

$1.42(0.24-2.57)$

$P=0.189$

$3.45(0.33-5.95)$

$P=0.087$

$4.18(0.00-13.56)$

$0.00(0.00-0.00)$

$P=0.284$

$0.00(0.00-0.00)$

$P=0.284$

$18.19(0.00-45.76)$

$8.58(0.00-30.49)$

$P=0.270$

$29.44(0.00-61.88)$

$P=0.513$

At onset of febrile $19.56(0.00-58.92)$ episodes

mean (range)

\begin{tabular}{|c|c|c|}
\hline $\begin{array}{l}15.12(0.65-51.65) \\
P=0.117\end{array}$ & $\begin{array}{l}40.28(0.01-242.45) \\
P=0.081\end{array}$ & $\begin{array}{l}16.11(7.86-21.26) \\
P=0.130\end{array}$ \\
\hline $\begin{array}{l}22.59(0.65-51.65) \\
P=0.036\end{array}$ & $\begin{array}{l}48.82(0.01-242.45) \\
P=0.025\end{array}$ & $\begin{array}{l}22.08(14.81-36.01) \\
P=0.081\end{array}$ \\
\hline $0.99(0.17-2.03)$ & $1.72(0.00-4.09)$ & $6.47(2.79-8.49)$ \\
\hline $\begin{array}{l}2.07(0.24-4.61) \\
P=0.049\end{array}$ & $\begin{array}{l}4.65(0.17-17.65) \\
P=0.036\end{array}$ & $\begin{array}{l}2.65(1.07-4.28) \\
P=0.123\end{array}$ \\
\hline $\begin{array}{l}2.73(0.33-6.89) \\
P=0.029\end{array}$ & $\begin{array}{l}5.70(0.33-17.65) \\
P=0.004\end{array}$ & $\begin{array}{l}3.56(2.49-4.85) \\
P=0.193\end{array}$ \\
\hline $0.60(0.00-6.57)$ & $0.50(0.00-8.44)$ & $23.00(0.00-79.09)$ \\
\hline $\begin{array}{l}0.00(0.00-0.00) \\
P=0.341\end{array}$ & $\begin{array}{l}0.00(0.00-0.00) \\
P=0.332\end{array}$ & $\begin{array}{l}0.00(0.00-0.00) \\
P=0.309\end{array}$ \\
\hline $\begin{array}{l}0.24(0.00-2.65) \\
P=0.604\end{array}$ & $\begin{array}{l}0.00(0.00-0.00) \\
P=0.332\end{array}$ & $\begin{array}{l}0.66(0.00-2.65) \\
P=0.327\end{array}$ \\
\hline $13.29(0.00-61.16)$ & $9.00(0.00-86.03)$ & $27.66(0.00-73.44)$ \\
\hline $\begin{array}{l}15.54(0.00-81.23) \\
P=0.438\end{array}$ & $\begin{array}{l}25.10(0.00-222.88) \\
P=0.120\end{array}$ & $\begin{array}{l}2.05(0.00-8.19) \\
P=0.165\end{array}$ \\
\hline $\begin{array}{l}19.59(0.00-81.23) \\
P=0.123\end{array}$ & $\begin{array}{l}32.51(0.00-222.88) \\
P=0.029\end{array}$ & $\begin{array}{l}9.12(0.00-28.28) \\
P=0.335\end{array}$ \\
\hline $28.30(0.00-93.30)$ & $35.34(0.00-171.23)$ & $86.33(52.26-151.73)$ \\
\hline
\end{tabular}

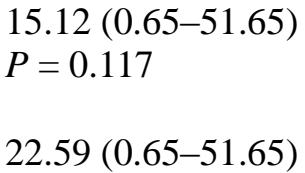

$40.28(0.01-242.45)$
$P=0.081$

$48.82(0.01-242.45)$
$16.11(7.86-21.26)$

22.08 (14.81-36.01)

$6.47(2.79-8.49)$

.65 (1.07-4.28)

$3.56(2.49-4.85)$ 


\begin{tabular}{|c|c|c|c|c|c|}
\hline & $\begin{array}{l}\text { At neutrophil recovery } \\
\text { mean (range) }\end{array}$ & $\begin{array}{l}57.95(2.25-92.77) \\
P=0.067\end{array}$ & $\begin{array}{l}42.53(18.52-121.42) \\
P=0.002\end{array}$ & $\begin{array}{l}50.53(0.00-152.82) \\
P=0.208\end{array}$ & $\begin{array}{l}62.85(12.94-121.42) \\
P=0.417\end{array}$ \\
\hline & $P$ value (vs. at onset) & & & & \\
\hline & At EOT & $86.05(49.26-142.46)$ & $46.71(10.40-158.79)$ & $63.72(7.02-152.82)$ & $59.81(12.94-158.79)$ \\
\hline & $\begin{array}{l}\text { mean (range) } \\
P \text { value (vs. at onset) }\end{array}$ & $P=0.088$ & $P=0.011$ & $P=0.016$ & $P=0.224$ \\
\hline \multirow[t]{5}{*}{$\begin{array}{l}\text { FGF } \\
(<55.00)\end{array}$} & $\begin{array}{l}\text { At onset of febrile } \\
\text { episodes } \\
\text { mean (range) }\end{array}$ & $31.77(0.00-59.32)$ & $27.89(0.00-76.93)$ & $22.97(0.00-121.73)$ & $52.73(0.00-93.83)$ \\
\hline & At neutrophil recovery & $35.08(12.41-55.45)$ & $32.49(0.00-79.95)$ & $32.22(0.00-153.38)$ & $34.72(0.00-52.96)$ \\
\hline & $\begin{array}{l}\text { mean (range) } \\
P \text { value (vs. at onset) }\end{array}$ & $P=0.802$ & $P=0.414$ & $P=0.156$ & $P=0.203$ \\
\hline & At EOT & $59.31(21.53-92.07)$ & $39.44(0.00-79.95)$ & $43.35(0.00-153.38)$ & $41.99(0.00-66.42)$ \\
\hline & $\begin{array}{l}\text { mean (range) } \\
P \text { value (vs. at onset) }\end{array}$ & $P=0.088$ & $P=0.196$ & $P=0.002$ & $P=0.420$ \\
\hline \multirow[t]{5}{*}{ G-CSF $(<1.50)$} & $\begin{array}{l}\text { At onset of febrile } \\
\text { episodes } \\
\text { mean (range) }\end{array}$ & $\begin{array}{l}482.22 \\
(43.10-1354.55)\end{array}$ & $\begin{array}{l}692.37 \\
(0.00-3485.95)\end{array}$ & $\begin{array}{l}1124.57 \\
(0.00-5366.01)\end{array}$ & $55.50(2.31-135.23)$ \\
\hline & $\begin{array}{l}\text { At neutrophil recovery } \\
\text { mean (range) } \\
P \text { value (vs. at onset) }\end{array}$ & $\begin{array}{l}44.26(16.00-92.12) \\
P=0.242\end{array}$ & $\begin{array}{l}467.41 \\
(0.00-2564.71) \\
P=0.638\end{array}$ & $\begin{array}{l}205.10 \\
(0.00-1391.43) \\
P=0.008\end{array}$ & $\begin{array}{l}14.85(10.54-17.49) \\
P=0.272\end{array}$ \\
\hline & At EOT & $17.18(3.60-27.55)$ & 260.73 & $87.03(0.00-482.83)$ & $14.66(9.96-20.66)$ \\
\hline & mean (range) & $P=0.209$ & $(0.00-2564.71)$ & $P=0.010$ & $P=0.264$ \\
\hline & $P$ value (vs. at onset) & & $P=0.355$ & & \\
\hline \multirow[t]{5}{*}{$\begin{array}{l}\text { GM-CSF } \\
(<122.00)\end{array}$} & $\begin{array}{l}\text { At onset of febrile } \\
\text { episodes } \\
\text { mean (range) }\end{array}$ & $0.75(0.00-0.30)$ & $1.74(0.00-17.20)$ & $2.02(0.00-20.77)$ & $47.37(0.00-159.75)$ \\
\hline & At neutrophil recovery & $0.88(0.00-3.01)$ & $0.78(0.00-7.82)$ & $3.36(0.00-24.55)$ & $0.83(0.00-2.55)$ \\
\hline & $\begin{array}{l}\text { mean (range) } \\
P \text { value (vs. at onset) }\end{array}$ & $P=0.301$ & $P=0.604$ & $P=0.576$ & $P=0.310$ \\
\hline & At EOT & $6.25(0.00-17.05)$ & $2.38(0.00-10.22)$ & $4.16(0.00-24.55)$ & $3.19(0.00-10.22)$ \\
\hline & mean (range) & $P=0.229$ & $P=0.774$ & $P=0.355$ & $P=0.341$ \\
\hline $\mathrm{IFN}-\gamma(<124.00)$ & $\begin{array}{l}P \text { value (vs. at onset) } \\
\text { At onset of febrile } \\
\text { episodes } \\
\text { mean (range) }\end{array}$ & $30.98(14.07-39.71)$ & $8.24(0.00-44.28)$ & $22.72(0.00-78.38)$ & $70.48(23.27-112.03)$ \\
\hline
\end{tabular}




\begin{tabular}{|c|c|c|c|c|c|}
\hline & $\begin{array}{l}\text { At neutrophil recovery } \\
\text { mean (range) }\end{array}$ & $\begin{array}{l}40.85(15.15-63.61) \\
P=0.291\end{array}$ & $\begin{array}{l}17.94(0.00-42.02) \\
P=0.190\end{array}$ & $\begin{array}{l}40.71(0.20-116.46) \\
P=0.098\end{array}$ & $\begin{array}{l}43.46(0.00-98.83) \\
P=0.270\end{array}$ \\
\hline & $P$ value (vs. at onset) & & & & \\
\hline & At EOT & 70.67 (23.43-98.72) & $29.64(0.00-77.48)$ & $48.19(1.62-116.46)$ & $51.09(0.00-98.83)$ \\
\hline & mean (range) & $P=0.067$ & $P=0.068$ & $P=0.015$ & $P=0.441$ \\
\hline & $P$ value (vs. at onset) & & & & \\
\hline \multirow[t]{7}{*}{ IP-10 $(<637.00)$} & $\begin{array}{l}\text { At onset of febrile } \\
\text { episodes } \\
\text { mean (range) }\end{array}$ & $\begin{array}{l}4237.89 \\
(857.74-12420.88)\end{array}$ & $\mathrm{NE}(255.75-\mathrm{OOR}>)$ & $\mathrm{NE}(512.48-\mathrm{OOR}>)$ & $\begin{array}{l}10295.80 \\
(1762.24-26535.19)\end{array}$ \\
\hline & At neutrophil recovery & 2232.25 & $\mathrm{NE}(580.18-\mathrm{OOR}>)$ & 2857.92 & NE $(1154.97-$ OOR $>)$ \\
\hline & mean (range) & $(580.18-6487.64)$ & Not calculated & $(112.25-6735.49)$ & Not calculated \\
\hline & $P$ value (vs. at onset) & $P=0.228$ & & Not calculated & \\
\hline & At EOT & 2527.81 & $\mathrm{NE}(467.51-\mathrm{OOR}>)$ & NE $\quad(1603.34-$ & $\mathrm{NE}(467.51-\mathrm{OOR}>)$ \\
\hline & mean (range) & $(545.84-6163.34)$ & Not calculated & OOR>) & Not calculated \\
\hline & $P$ value (vs. at onset) & $P=0.645$ & & Not calculated & \\
\hline \multirow[t]{6}{*}{ MCP-1 $(<48.00)$} & $\begin{array}{l}\text { At onset of febrile } \\
\text { episodes } \\
\text { mean (range) }\end{array}$ & $\begin{array}{l}218.95 \\
(120.19-323.41)\end{array}$ & $\begin{array}{l}236.58 \\
(17.25-903.27)\end{array}$ & $\begin{array}{l}113.61 \\
(13.96-322.98)\end{array}$ & $250.81(18.47-654.40)$ \\
\hline & $\begin{array}{l}\text { At neutrophil recovery } \\
\text { mean (range) }\end{array}$ & $\begin{array}{l}33.32(10.33-71.25) \\
P=0.029\end{array}$ & $\begin{array}{l}62.00(8.10-251.78) \\
P=0.065\end{array}$ & $\begin{array}{l}52.91(4.46-240.56) \\
P=0.015\end{array}$ & $\begin{array}{l}41.35(16.40-73.62) \\
P=0.234\end{array}$ \\
\hline & $P$ value (vs. at onset) & & & & \\
\hline & At EOT & $15.13(8.40-28.15)$ & $29.92(7.45-73.44)$ & 47.07 (7.04-225.13) & $43.48(16.40-73.62)$ \\
\hline & mean (range) & $P=0.034$ & $P=0.032$ & $P=0.012$ & $P=0.241$ \\
\hline & $P$ value (vs. at onset) & & & & \\
\hline \multirow[t]{6}{*}{ MIP-1 $\alpha(<2.00)$} & $\begin{array}{l}\text { At onset of febrile } \\
\text { episodes } \\
\text { mean (range) }\end{array}$ & $4.18(0.93-5.89)$ & $4.86(0.98-9.44)$ & $2.91(0.00-11.36)$ & $3.57(0.73-6.11)$ \\
\hline & At neutrophil recovery & $2.81(1.73-3.46)$ & $3.25(0.65-9.32)$ & $3.52(0.62-12.61)$ & $3.02(1.23-4.43)$ \\
\hline & mean (range) & $P=0.222$ & $P=0.070$ & $P=0.103$ & $P=0.504$ \\
\hline & At EOT & $4.49(2.03-6.49)$ & $363\left(\begin{array}{ll}0 & 32-9 \\
\end{array}\right.$ & $432(065-1261)$ & $394(328-443)$ \\
\hline & mean (range) & $P=0.744$ & $P=0.234$ & $P=0.004$ & $P=0.741$ \\
\hline & $P$ value (vs. at onset) & & & & \\
\hline $\begin{array}{l}\text { PDGF- } \beta \beta \\
(<3667.00)\end{array}$ & $\begin{array}{l}\text { At onset of febrile } \\
\text { episodes } \\
\text { mean (range) }\end{array}$ & $199.38(74.00-315.15)$ & $150.66(7.16-308.23)$ & 223.62 (1.72-905.63) & $\begin{array}{l}3518.79 \\
(339.63-11117.02)\end{array}$ \\
\hline
\end{tabular}




\begin{tabular}{|c|c|c|c|c|c|}
\hline & At neutrophil recovery & 303.66 & 523.74 & 1129.45 & 348.01 \\
\hline & mean (range) & $(116.08-510.16)$ & $(21.22-2111.39)$ & (41.94-5370.62) & $(134.25-585.62)$ \\
\hline & $P$ value (vs. at onset) & $P=0.161$ & $P=0.064$ & $P=0.038$ & $P=0.291$ \\
\hline & At EOT & 1005.25 & 695.07 & 1418.98 & 605.60 \\
\hline & mean (range) & $(41.52-2837.45)$ & (1.07-2111.39) & $(61.02-5370.62)$ & $(134.25-1396.56)$ \\
\hline & $P$ value (vs. at onset) & $P=0.278$ & $P=0.018$ & $P=0.006$ & $P=0.342$ \\
\hline \multirow[t]{6}{*}{ MIP-1 $\beta(<47.00)$} & $\begin{array}{l}\text { At onset of febrile } \\
\text { episodes } \\
\text { mean (range) }\end{array}$ & $\begin{array}{l}307.85 \\
(102.81-626.84)\end{array}$ & $\begin{array}{l}126.20 \\
(17.06-557.60)\end{array}$ & 60.07 (22.01-153.62) & 107.47 (51.42-199.88) \\
\hline & At neutrophil recovery & $102.71(66.43-134.04)$ & 61.34 (23.64-105.44) & $68.46(2.60-174.95)$ & $53.80(26.86-76.40)$ \\
\hline & $\begin{array}{l}\text { mean (range) } \\
P \text { value (vs. at onset) }\end{array}$ & $P=0.195$ & $P=0.175$ & $P=0.43$ & $P=0.234$ \\
\hline & At EOT & 136.31 & $59.04(23.64-113.23)$ & $75.70(26.99-145.43)$ & $62.96(26.86-85.73)$ \\
\hline & mean (range) & (103.68-218.45) & $P=0.159$ & $P=0.084$ & $P=0.360$ \\
\hline & $P$ value (vs. at onset) & $P=0.241$ & & & \\
\hline \multirow[t]{5}{*}{$\begin{array}{l}\text { RANTES } \\
(<2282.00)\end{array}$} & $\begin{array}{l}\text { At onset of febrile } \\
\text { episodes } \\
\text { mean (range) }\end{array}$ & $\begin{array}{l}1561.64 \\
(552.01-2229.87)\end{array}$ & $\mathrm{NE}(408.06-\mathrm{OOR}>)$ & $\mathrm{NE}(490.45-\mathrm{OOR}>)$ & $\mathrm{NE}(\mathrm{OOR}>-\mathrm{OOR}>)$ \\
\hline & At neutrophil recovery & NE $(1090.28-$ OOR>) & NE (1090.28-OOR>) & NE (394.37- OOR>) & $\mathrm{NE}(3313.00-\mathrm{OOR}>)$ \\
\hline & $\begin{array}{l}\text { mean (range) } \\
P \text { value (vs. at onset) }\end{array}$ & Not calculated & Not calculated & Not calculated & Not calculated \\
\hline & At EOT & NE (3622.71- OOR>) & NE (524.79-OOR>) & NE (425.96- OOR>) & $\mathrm{NE}(\mathrm{OOR}>-\mathrm{OOR}>)$ \\
\hline & mean (range) & Not calculated & Not calculated & Not calculated & Not calculated \\
\hline \multirow[t]{5}{*}{ TNF- $\alpha(<98.00)$} & $\begin{array}{l}P \text { value (Vs. at onset) } \\
\text { At onset of febrile } \\
\text { episodes } \\
\text { mean (range) }\end{array}$ & $17.83(4.14-34.98)$ & $6.66(0.00-14.12)$ & $23.31(0.00-197.45)$ & $29.88(10.00-57.12)$ \\
\hline & At neutrophil recovery & $22.65(8.85-36.28)$ & $11.97(0.00-30.85)$ & $17.06(0.00-53.84)$ & $18.91(5.46-35.28)$ \\
\hline & $\begin{array}{l}\text { mean (range) } \\
P \text { value (vs. at onset) }\end{array}$ & $P=0.242$ & $P=0.092$ & $P=0.520$ & $P=0.108$ \\
\hline & At EOT & $35.74(14.24-51.56)$ & $16.59(0.00-46.96)$ & $20.96(1.38-53.84)$ & $25.93(5.46-46.96)$ \\
\hline & $\begin{array}{l}\text { mean (range) } \\
P \text { value (vs. at onset) }\end{array}$ & $P=0.132$ & $P=0.050$ & $P=0.808$ & $P=0.679$ \\
\hline VEGF $(<9.00)$ & $\begin{array}{l}\text { At onset of febrile } \\
\text { episodes } \\
\text { mean (range) }\end{array}$ & $20.79(6.30-34.92)$ & $13.16(0.00-32.12)$ & $15.88(0.00-64.91)$ & $299.48(19.82-660.84)$ \\
\hline
\end{tabular}




$\begin{array}{lllll}\text { At neutrophil recovery } & 18.37(7.05-31.12) & \begin{array}{l}23.73(0.00-142.90) \\ \text { mean (range) }\end{array} & P=0.702 .20(0.00-847.74) & 19.75(5.73-36.75) \\ P \text { value (vs. at onset) } & & & P=0.122 & P=0.139 \\ \text { At EOT } & 47.65(10.37-95.21) & 42.55(0.00-142.90) & 117.13(0.00-847.74) & 38.98(11.70-96.02) \\ \text { mean (range) } & P=0.217 & P=0.087 & P=0.067 & P=0.113\end{array}$

*Abbreviations: EOT, end of intravenous antibiotic therapy; OOR>, out of range above; IL, interleukin; FGF, fibroblast growth factor; G-CSF, granulocyte-colony stimulating factor; GM-CSF, granulocyte-macrophage colony stimulating factor; IFN- $\gamma$, interferon- $\gamma$; IP-10, interferon gamma inducible protein-10; MCP-1, monocyte chemoattractant-1; MIP-1 $\alpha$, macrophage inflammatory protein- $1 \alpha$; PDGF- $\beta \beta$, platelet derived growth factor- $\beta \beta$; RANTES, regulated on activation, normal T cell expressed and secreted; TNF- $\alpha$, tumor necrosis factor- $\alpha$; VEGF, vascular endothelial growth factor.

$\dagger$ The upper limit data are cited from the serum data of healthy controls (reference 25). 
Supplementary Table 2. Diagnostic performance of serum levels of 27 cytokines and chemokines at onset of febrile episodes for sepsis or bacterial infections $(n=36)$

\begin{tabular}{|c|c|c|}
\hline & $\begin{array}{l}\text { AUC }(95 \% \text { CI, } P) \\
\text { Sepsis vs. others }\end{array}$ & $\begin{array}{l}\text { AUC }(95 \% \text { CI, } P) \\
+ \text { Bacterial infections vs. others }\end{array}$ \\
\hline \multicolumn{3}{|c|}{$\begin{array}{l}\text { Cytokines and chemokines (normal reference } \\
\text { ranget, } \mathrm{pg} / \mathrm{ml} \text { ) }\end{array}$} \\
\hline $\mathrm{IL}-1 \beta(<0.70)$ & $0.652(95 \%$ CI $0.436-0.869, P=0.326)$ & $0.432(95 \%$ CI $0.241-0.622, P=0.490)$ \\
\hline IL-1 receptor antagonist $(<665.00)$ & $0.586(95 \%$ CI $0.280-0.892, P=0.580)$ & $0.489(95 \%$ CI $0.297-0.681, P=0.911)$ \\
\hline IL-2 $(<90.00)$ & $0.555(95 \%$ CI $0.219-0.890, P=0.725)$ & $0.511(95 \%$ CI $0.316-0.706, P=0.911)$ \\
\hline IL-4 (<3.00) & $0.656(95 \%$ CI $0.406-0.907, P=0.314)$ & $0.438(95 \%$ CI $0.246-0.630, P=0.532)$ \\
\hline IL-5 $(<7.00)$ & $0.531(95 \%$ CI $0.244-0.819, P=0.840)$ & $0.294(95 \%$ CI $0.116-0.472, P=0.037)$ \\
\hline IL-6 $(<9.00)$ & $0.789(95 \%$ CI $0.591-0.987, P=0.063)$ & $0.594(95 \%$ CI $0.395-0.792, P=0.344)$ \\
\hline IL-7 (<13.00) & $0.648(95 \%$ CI $0.462-0.835, P=0.339)$ & $0.543(95 \%$ CI $0.349-0.737, P=0.665)$ \\
\hline IL-8 $(<116.00)$ & $0.844(95 \%$ CI $0.618-1.00, P=0.027)$ & $0.651(95 \%$ CI $0.447-0.855, P=0.127)$ \\
\hline IL-9 $(<500.00)$ & $0.680(95 \%$ CI $0.432-0.928, P=0.247)$ & $0.517(95 \%$ CI $0.325-0.710, P=0.860)$ \\
\hline
\end{tabular}


$\mathrm{IL}-10(<2.00)$

IL-12 $(<6.00)$

IL-13 (<9.00)

IL-15 (<5.00)

IL-17 (<31.00)

Eotaxin $(<39.00)$

FGF basic $(<55.00)$

G-CSF $(<1.50)$

GM-CSF $(<122.00)$

IFN- $\gamma(<124.00)$

IP-10 $(<637.00)$

MCP-1 $(<48.00)$
$0.641(95 \%$ CI $0.300-0.981, P=0.365)$

$0.563(95 \%$ CI $0.237-0.888, P=0.687)$

$0.250(95 \%$ CI $0.070-0.430, P=0.107)$

$0.672(95 \%$ CI $0.358-0.985, P=0.268)$

$0.586(95 \%$ CI $0.280-0.892, P=0.580)$

0.313 (95\%CI $0.00-0.630, P=0.227)$

$0.559(95 \%$ CI $0.279-0.839, P=0.706)$

0.508 (95\%CI 0.283-0.733, $P=0.960)$

0.477 (95\%CI 0.197-0.756, $P=0.880)$

0.664 (95\%CI $0.494-0.835, P=0.290)$

$0.539(95 \%$ CI $0.242-0.836, P=0.801)$

$0.703(95 \%$ CI $0.526-0.880, P=0.191)$
$0.548(95 \%$ CI $0.344-0.751, P=0.630)$

0.479 (95\%CI 0.285-0.674, $P=0.835$ )

$0.289(95 \%$ CI $0.116-0.462, P=0.033)$

$0.502(95 \%$ CI $0.308-0.695, P=0.987)$

0.575 (95\%CI $0.382-0.767, P=0.451)$

0.367 (95\%CI 0.181-0.552, $P=0.178$ )

0.573 (95\%CI $0.383-0.763, P=0.461)$

0.471 (95\%CI 0.279-0.663, $P=0.773$ )

0.444 (95\%CI 0.255-0.634, $P=0.574$ )

0.359 (95\%CI 0.179-0.538, $P=0.153$ )

0.438 (95\%CI $0.235-0.641, P=0.532)$

0.600 (95\%CI 0.395-0.805, $P=0.312)$ 
MIP-1 $\alpha(<2.00)$

PDGF- $\beta \beta(<3667.00)$

$\operatorname{MIP}-1 \beta(<47.00)$

RANTES $(<2282.00)$

TNF- $\alpha(<98.00)$

$\operatorname{VEGF}(<9.00)$
$0.602(95 \%$ CI $0.288-0.915, P=0.513)$

$0.531(95 \%$ CI $0.312-0.751, P=0.840)$

$0.898(95 \%$ CI $0.768-1.00, P=0.010)$

$0.266(95 \%$ CI $0.085-0.446, P=0.131)$

$0.680(95 \%$ CI $0.419-0.940, P=0.247)$

0.594 (95\%CI 0.364-0.824, $P=0.546)$
0.702 (95\%CI 0.519-0.884, $P=0.042)$

$0.416(95 \%$ CI $0.227-0.605, P=0.395)$

$0.660(95 \%$ CI $0.465-0.855, P=0.105)$

$0.357(95 \%$ CI $0.169-0.545, P=0.149)$

$0.383(95 \%$ CI $0.198-0.567, P=0.235)$

0.443 (95\%CI $0.253-0.633, P=0.564)$

*Abbreviations: AUC, area under the curve; IL, interleukin; FGF, fibroblast growth factor; G-CSF, granulocyte-colony stimulating factor; GM-CSF, granulocyte-macrophage colony stimulating factor; IFN- $\gamma$, interferon- $\gamma$; IP-10, interferon gamma inducible protein-10; MCP-1, monocyte chemoattractant- 1 ; MIP- $1 \alpha$, macrophage inflammatory protein- $1 \alpha$; PDGF- $\beta \beta$, platelet derived growth factor- $\beta \beta$; RANTES, regulated on activation, normal $\mathrm{T}$ cell expressed and secreted; TNF- $\alpha$, tumor necrosis factor- $\alpha$; VEGF, vascular endothelial growth factor.

$\dagger$ Bacterial infections are defined as sepsis or local infections.

$\$$ The upper limit data are cited from the serum data of healthy controls (reference 25). 